\title{
7 \\ The Life Histories of Three Uzbek Migrant Workers in Russia
}

This chapter presents the life histories of three male Uzbek migrants in Moscow, which I label the "three heroes of the book." These men experienced many challenges during their initial migrant periods and then successfully adapted into the labor market and host society given their knowledge of the informal rules of survival and street life and their ability to adapt to changing circumstances. These three life histories resulted from my extensive ethnographic fieldwork carried out between 2014 and 2018 in Moscow and the Fergana Valley (Uzbekistan). Throughout that period I maintained regular contact with these three heroes and closely observed the developments in their life through intensive fieldwork site visits and smartphone-based communication. This difficult endeavor was possible given that the three heroes and I all hail from the same region in Uzbekistan, which enabled me to build a trustworthy relationship with my heroes and gain access to their daily lives and mundane activities in Moscow. Observing their lives afforded me the opportunity to collect their narratives related to informal adaptation and the street world and to observe situations where they maneuvered around immigration and labor laws and solved problems through informal rules and channels. I present these life histories in a separate chapter primarily to explore-ethnographically and biographically-the interconnections between various structural and individual factors described in the previous chapters. This presentation allows me construct how migrants maneuver through the Russian legal system and among the police, immigration officials, and border guards, and how they produce various forms of informal governance and legal order to organize their daily lives. Throughout what follows, I use pseudonyms for all three of these heroes and all of the other individuals that appear in the life histories.

The first case focuses on Zaur, an undocumented migrant who works in a supermarket and receives a proper salary (comparable to a Russian citizen's salary) 
thanks to his fake Russian passport. The second case revolves around the adventures of Nodir, an undocumented labor migrant linked to street institutions and who works as a guard and caretaker at a dacha (summer cottage) in Rublevka, Moscow, a property owned by a high-level official in the Russian Federal Security Service (FSB). The third case focuses on Baha, a loader at a warehouse, who experienced various hardships given his attempt to comply with Russian immigration laws. He later succeeded by using informal means of legal adaptation. The sections that follow provide the "thick descriptions" presented through these three life histories.

\section{ZAUR: BECOMING “RUSSKIY” (RUSSIAN) THROUGH INFORMAL PRACTICES}

Zaur (35, male), a migrant worker in Moscow, comes from the Fergana Valley in Uzbekistan. He arrived in Moscow in 2003 shortly after finishing secondary school in rural Fergana. Before traveling to Moscow, he worked as a broker in his home village, a seasonal summer job where he bought fruits and vegetables in large quantities from individual farmers (dehqonlar) and distributed them to village-based informal entrepreneurs (rossiychilar) at a wholesale price. Typically, rossiychilar export these products to different bazaars in large Russian cities. All of these transactions take place without prefinancing and rely on trust and an oral contract, whereby the rossiychilar are expected to sell all of the products in Russia and then pay the brokers for the products they provided. In turn, the brokers are expected to distribute the promised money to individual farmers. Zaur's brokerage business created more trouble than profit, however, since informal entrepreneurs who bought his products went bankrupt and failed to pay Zaur's expenses. As a result Zaur also found himself indebted to several individual farmers who typically relied on the summer harvests to make ends meet. These events and the resulting daily pressure placed on him by various farmers eventually forced Zaur to leave his home village and search for job opportunities in Russia.

Zaur arrived in Moscow in the autumn of 2003, when labor migration remained a new phenomenon in Russia. But Zaur quickly adapted to the new environment, given that his classmate Mirzo was already working in Moscow and helped him find a job at a furniture factory. His salary was 21,000 rubles ( US $\$ 700$ based on 2003 exchange rates), and he worked at the furniture factory until 2007 without a work permit or employment contract. Given his stable monthly salary, which was considered high compared to typical wages in Uzbekistan, Zaur paid off his debts to farmers in one-year's time, allowing him to use his remittances to buy a fancy car for his parents and renovate their house in his home village. This granted Zaur and his family a higher social status and reputation in the village, which probably would not have happened so quickly if Zaur had remained in the village. 
But Zaur lost his job in 2007 because of the tightening of immigration laws in Russia, which forced many employers to hire migrants with proper work permits and residence registration documents. Given his undocumented status, Zaur was forced to work in the construction sector for one year, a sector in which he could work without documents. Because construction work is considered "black work" (qora ish) among migrants, Zaur did not remain in this sector long. Fortunately, he had many connections from the street world through which he could "legalize" his status and, subsequently, returned to his former job at the furniture factory. In December of 2007 , for a fee of 8,000 rubles ( US\$250 based on 2007 exchange rates), he bought a fake Russian passport and became a "Russian citizen" with a different name and place of birth, which situated him as an Uzbek born in southern Kyrgyzstan. This removed his connection to Uzbekistan completely from his new fake Russian passport. Since his Russian passport was nicely designed and identical to an authentic passport, Zaur managed to convince his Russian boss at the furniture factory that he had indeed received Russian citizenship by bribing a high-level official at the Federal Migration Service. Thanks to this new legal status, he easily returned to his old job at the furniture factory, but he was now hired as a Russian citizen and received a monthly salary of 45,000 rubles ( $\sim$ US $\$ 1,500$ based on 2007 exchange rates), an income level comparable to an average Muscovite's salary. Like typical Russians, he worked there only five days a week and took two days off during the weekends, although he continued to receive a salary twice as high as his covillagers, a position granting him the nickname Russkiy (Russian) among his village network in Moscow.

Zaur's success did not last a year. In August of 2008, on his way to his workplace, he was stopped by a police officer who asked for his identity documents. Without even thinking of the possible consequences, Zaur confidently showed him his Russian passport, proudly stating that he held Russian citizenship. But his confident voice did not convince the police officer who previously dealt with many similar cases and decided to check the authenticity of his passport at the police department. After carefully checking his passport against a database, the police officer identified his passport as a fake and informed Zaur that he had prepared an arrest report and was transferring his case to a public prosecutor, recommending that a criminal case be opened. It was highly likely that Zaur would be charged with document forgery, a criminal act according to Article 327 of the Russian Criminal Code. Not wanting to end up in prison, Zaur quickly found a Russian defense lawyer through his street connections in Moscow. His defense lawyer was street-smart and well-versed in bribery. Rather than trying to defend him in court, he asked Zaur to give him 30,00o rubles ( US\$1,000), which would be given to the public prosecutor who agreed to change Zaur's case from a criminal charge to an administrative offense, resulting in a fine and deportation to Uzbekistan. The public prosecutor kept his word, and Zaur received a fine along with an 
administrative expulsion and deportation order. After spending three months in the temporary detention center at Dmitrievskoe Shosse in Moscow, Zaur was deported to Uzbekistan in November of 2008, with an entry ban for the next five years (until 2013).

After returning to his village, Zaur married in 2009 and started a new life. But because he had worked in Moscow for many years and was accustomed to receiving a good salary, he could not readapt to the low pay and working conditions in rural Fergana. His salary was insufficient to secure even his family's basic needs. Working as a broker was not an option given his past experience with the rossiychilar. In his words he had already become "Russified" (o'rishlashib ketdim) and longed for his migrant life in Moscow. His desire to return to Moscow prompted him to develop new strategies. In March of 2011, after long negotiations and efforts, he managed to find common ground ( $t$ il topishdi) with an Uzbek police officer in his home district willing to assist Zaur in changing his name and obtaining a new passport for a gratuity payment of US\$500. As a result, Zaur was now “clean," and he returned to Moscow in April 2011 as a migrant who had previously never been to Russia.

This time, given his previous bad experience with a forged passport, Zaur was determined to become "legal" (qonuniy bo'lib yurish) and follow all Russian laws. Zaur knew that his name was clean and that none of his previous offenses existed in the Russian state database because of his new name. But, going "legal" in Zaur's view meant renewing his migration card and exit-entry stamp every 90 days at the Russian-Ukrainian border. This process allowed many Central Asian migrants to remain legally within the territory of the Russian Federation, but this legal stay was limited to visitors and did not allow migrants to work in Russia.

Because Zaur was away from Moscow for nearly three years, things were different in the migrant labor market. After arriving in Moscow in April of 2011, he tried to return to his old job at the furniture factory, but he found no vacant positions there. Additionally, they knew Zaur's history with the fake Russian passport, which probably was the main reason they chose not to rehire him. Since he could not secure a stable job, Zaur had to work in many places until May of 2014, when he was again deported to Uzbekistan. Between April of 2011 and May of 2014, he worked as an electrician, a loader in a bazaar, a dacha caretaker, and a construction worker, earning on average of 18 , 00o to 20 , 000 rubles ( $\sim$ US $\$ 500-$ $\$ 650$ based on 2011-14 exchange rates) per month. Zaur worked in all of these different jobs without a work permit since they were all based on a handshake agreement. In order to remain "legal," Zaur traveled by shared taxi to the Pogar border point (Russian-Ukrainian border) in the Bryansk province every 90 days. There he could renew his migration card and get a new exit-entry stamp in his passport, allowing him to stay another 90 days in Russia.

In May of 2014, FMS, with assistance from OMON (the Russian paramilitary police), conducted a raid at the construction site in the Moscow province 
where many Uzbek migrants worked. With other migrants Zaur was also apprehended during this raid. Since all of the migrants worked there without any formal contracts or work permits, their cases were transferred to the courts for trial and possible deportation. Before the court proceedings, Zaur and all of the other migrants were brought to the police department, where migrants were kept in a cell prior to trial. Knowing that all Russian police officers take bribes, Zaur offered 15,000 rubles ( $\sim$ US $\$ 450$ ) to one police officer there. But the officer refused the bribe with regret, stating that FMS was involved in this case, and, therefore, the officer was not in a position to take bribes.

As expected, the next day, Zaur, like other migrants, was fined 10,000 rubles $(\sim \mathrm{US} \$ 300)$ and received an administrative expulsion and deportation order with a five-year entry ban. He was then transferred to a temporary detention center (Spetsial'noe uchrezhdenie vremennego soderzhaniya inostrannikh grazhdan) in Moscow city, where he was kept for 18 days, until his deportation to Uzbekistan. Those 18 days that Zaur spent in the detention center turned out to be useful to him. Although the food and living conditions at the detention center were completely unacceptable, Zaur met a migrant worker from southern Kyrgyzstan who was street-smart and knew how to navigate around Russian laws. He told Zaur that he had a chance to return to Russia immediately if he managed to renew his passport within a month after his arrival in Uzbekistan. When Zaur asked him to explain more, he said that there was no shared database in Russia and each state institution-for instance, FMS, the police, and border control-has a separate database, and these different databases are only synchronized once a month. Even if a migrant is deported, this information exists only in the FMS database, and the border control service's database will only be updated one month later. Thus, migrants could easily enter Russia if they replace their old passport (with the deportation stamp) with a new one within 30 days. Not many migrants knew about this practice.

After being deported and arriving in rural Fergana in early June of 2014, Zaur moved quickly and secured a new passport in 12 days thanks to his connections at the district passport department. Immediately upon receiving his new passport, Zaur decided to travel to Russia by shared taxi rather than airplane, assuming that it would be safer to enter Russia through the Russian-Kazakh border, where, he believed, there was less control and more disorder. His tactic proved successful and he managed to get an entry stamp at the border, allowing him to continue his journey to Moscow, where he had good connections and knew how things worked.

Learning from his past mistakes, Zaur completely changed his strategy. He understood that he was already "illegal" in the FMS database, meaning that obtaining a real work permit and residence registration was an obvious impossibility. When Zaur worked in the wholesale bazaar, he was able to develop a friendly relationship with Mukhtar, an Azerbaijani immigrant in Moscow with Russian citizenship, who sold fruits and vegetables at a wholesale price. Coincidentally, Zaur's and Mukhtar's 
facial appearances were identical to the extent that a typical Russian would hardly distinguish between them. Given that Mukhtar was a Russia citizen and the similarity in their facial appearances, Zaur asked Mukhtar if he could use his Russian passport to get a job as a clerk at a supermarket, a position most Uzbek migrants in Moscow consider rather decent. This strategy rested on Zaur's understanding that for many Russians both Uzbek and Azerbaijani are cherniy (black) and, therefore, Russians can barely distinguish one cherniy from another.

In return, Zaur offered Mukhtar a 5,00o-ruble dolya (share) per month. Because Mukhtar worked informally in the bazaar, he did not accumulate any points for his pension. Given this fact, Zaur made clear to Mukhtar that he would be registered as formally employed in the state records and receive social security and pension contributions. Based on these benefits, Mukhtar gladly accepted Zaur's business proposal and even designed a more innovative strategy. Mukhtar said that Zaur could use his original passport when applying for a job at a supermarket and opening a bank account given that the original documents are required in such situations. If these two key steps are successfully passed, then, Mukhtar suggested that Zaur would carry with him two documents to keep him out of trouble when stopped by the police or other law-enforcement authorities: (1) a notarized copy of Mukhtar's passport, and (2) the original of his voenniy bilet (military ID), a document testifying that Mukhtar completed his military service in the Russian army. Both Zaur and Mukhtar agreed to these arrangements.

Events unfolded exactly as Zaur and Mukhtar anticipated. Zaur approached the manager of the supermarket with Mukhtar's passport. After a follow-up conversation, Zaur's job application was accepted, and he was subsequently employed as a Russian citizen with a 45,00o-ruble per month salary ( US $\$ 1,200$ based on June 2014 exchange rates) and two days off each week. He also managed to open a bank account at Sberbank and received a Mastercard for payments. Zaur was known as a Russian citizen in his workplace and received his salary in a bank account, a rarity among many migrants in Russia. Zaur also began enjoying free mobility in the city since the police check was no longer a problem for him. Each time he was stopped by the police, Zaur showed the notarized copy of his passport, together with the military ID, explaining that the original passport was currently at the public notary because of a sales contract issue.

In August of 2018, the last time I met Zaur in Moscow, he was still working at the same supermarket. Zaur was not alone this time. His wife was also in Moscow, working at the same supermarket with Zaur. Since Zaur had a good relationship with the supermarket manager, his wife could work at the supermarket informally, without any contract or documents. Given his Russkiy status, Zaur also managed to rent a three-bedroom apartment from the housing agency for 38,0oo rubles per month ( US $\$ 600$ based on August 2018 exchange rate), which he used to generate revenues by subletting two bedrooms and the living room to 12 migrants. This business covered his apartment rental fees, as well as generating 
an additional 12,00o-ruble ( US\$200) profit for Zaur. To keep the apartment free from police checks, Zaur paid a monthly bribe of 5 , 000 rubles ( $\sim \mathrm{US} \$ 80$ ) to the police officer in charge of the area near the apartment.

All in all, Zaur managed to change his social status from cherniy (black) to Russkiy (Russian) given his street smartness and his ability to develop various informal strategies to navigate the repressive legal system. Zaur used to listen to a song, "Moskva slezam ne verit" (Moscow sheds no tears), and believed that one must be creative and not afraid to take risks if s/he wanted to succeed in Moscow.

As shown above, given his street smartness and navigational skills, Zaur managed to adapt to the restrictive immigration legal regime in Russia. Because of normalized discrimination in the Russian labor market, where local workers with Russian citizenship received twice the pay migrant workers received, it was obvious that Zaur would not receive a decent salary even if he worked legally and possessed all of the required immigration documents. In addition to receiving a decent salary, Zaur also gained labor rights enabling him to complain about working conditions and claim overtime payment if he worked long hours. Hence, rather than trying to follow formal (legal) channels of legalization, which is almost unattainable given Russian realities, Zaur pursued alternative, informal paths of legal adaptation. These alternative paths provided him with greater economic security and relatively unimpeded mobility in a city notorious for police harassment and corruption.

\section{NODIR: STREET-LEVEL ADAPTATION}

Nodir (31, male) is a migrant from the Fergana Valley of Uzbekistan. He is a talkative, street-smart, physically fit individual. He has a rich experience in wrestling and street brawls, experiences confirmed by the many scars on his body. This history is also visible in his postschool career, during which he was involved in an unconventional income-earning activity. Shortly after finishing secondary school in 2004, Nodir started working as an ellik to'rtchi (fifty-four), a new term originating in the Fergana Valley, referring to individuals who illegally transport (or smuggle) cheap Chinese goods from Kyrgyzstan into Uzbekistan, items prohibited under Decree No. 154 of the Cabinet of Ministers of Uzbekistan ${ }^{1}$. While cheap Chinese products remain in strong demand, Uzbekistan continues to prohibit the importation of Chinese goods. This injunction stems from the vested interests of high-level state officials and business structures who established a monopoly over the provision of certain products by limiting the inflow of cheap Chinese products into Uzbekistan. Since these interests are formalized through a legislative act, Uzbek border guards and customs officials heavily control the inflow of these products.

As a smuggler, Nodir was to secretly transport Chinese goods and items (e.g., clothes, electronics, etc.) into the territory of Uzbekistan by means of cars provided by local entrepreneurs. He usually drove over the mountainous Kyrgyz-Uzbek border illegally through a roundabout way, a criminal act according to the Criminal 
Code of Uzbekistan. Frequently, he was spotted by Uzbek border guards who tried to chase him, but he always managed to escape them. Owing to his exceptional mountain-driving skills, many villagers used Nodir's nickname "Michael Schumacher," an internationally famous German race-car driver, when referring to him. But Nodir had to stop his smuggling activity in November of 2009 when the Uzbek government intensified its control over the Kyrgyz-Uzbek border, where border guards were instructed to shoot anyone crossing the border illegally. Not wanting to risk his life, he looked for alternative means to earn money, which led him to choose Russia as a new place to seek adventures. His decision to work in Russia was largely driven by the widespread trend in his village: all young men were migrating to Russia in search of better-paying jobs.

Nodir arrived in Moscow in mid-January of 2010. Like many Uzbek migrants, he worked without a work permit and regularly renewed his exit-entry stamp in his passport at the Russian-Ukrainian border every 90 days, allowing him to extend his legal stay in Russia. With the assistance of his village networks, he quickly found a job in the construction sector in the Moscow province. His tasks included various finishing and design works, such as window fitting, painting, flooring, and wallpaper installation. His monthly income was around 15,000 to 20,000 rubles ( $\sim$ US $\$ 450-\$ 600$ based on 2010 exchange rates). In this position he met many migrants from different villages of the Fergana Valley and established connections with the street world. These connections served as the basis for his new job as an extortion racketeer at Moscow's Kazansky railway station (hereafter, Kazansky vokzal).

Kazansky vokzal, situated at Komsomolskaya square, is one of nine railway stations in Moscow, which serves the Trans-Aral railway line (among others) departing to Kazakhstan, Kyrgyzstan, Tajikistan, and Uzbekistan. Therefore, when visiting this railway station, one may spot many migrants arriving from and departing to Central Asia. Given the high concentration of migrant workers at Kazansky vokzal, many cafés serve Central Asian food, and many underground printing houses produce fake immigration documents.

Since Nodir had already been involved in street-based informal economic activities in Uzbekistan, it was quite obvious that his premigratory experiences influenced his labor market behavior in Moscow. In April of 2011 Nodir, together with three migrants from the Fergana Valley, started a new "job" as an extortion racketeer at Kazansky vokzal. The main form of their racketeering activities involved forcibly extorting money from Kyrgyz, Tajik, and Uzbek migrants (departing to Central Asia) through threats and violence. If migrants had no money, Nodir and his team either took their mobile phones or took other valuable items from their bags. In turn, Nodir sold these phones and items at a market in Moscow's Savyolovskaya metro station, where visitors were predominantly Central Asian migrants. On average, each member of the racketeering team earned a monthly income of about 50,000 to 60,000 rubles ( $\sim$ US $\$ 1,500-\$ 1,800$ based on $2011-13$ exchange rates). 
Undoubtedly, Nodir and his team's racketeering activities represented criminal acts according to Russian legislation, which could lead to a seven-year prison sentence. They knew that they needed informal approval-that is, "roofing" (kryshevanie) from police officers at Kazansky vokzal-to continue their extortionist activities there. But Nodir was street-smart and managed to strike a deal with the Russian police officers. According to their informal agreement, Nodir was expected to give a weekly dolya (share or fee) of 10,000 rubles ( US\$30o), as well as secure their daily "recreational" needs such as cigarettes and vodka. In return, the police officers ignored their extortionist activities and did not react when migrants approached them for help. This informal agreement allowed Nodir and his team to freely and openly conduct their extortionist activities within the territory of the railway station.

I note here that Nodir and his team adhered to a moral code in their daily work. Since Nodir and his team members originated from the Fergana Valley, they remained loyal to their origins and never extorted money or other items from migrants who were also from the Fergana Valley. They also did not touch migrants from Uzbekistan's capital city of Tashkent, considering the historical fact that Tashkent was part of the Kokand Khanate, an Uzbek state in the Fergana Valley that existed from 1709 until 1876 within the territory of eastern Uzbekistan. Rather than extorting money, Nodir often recalled situations in which he helped and protected Fergana migrants in Moscow, when they needed money to buy a train ticket to Uzbekistan or asked for help with recovering their salary from middlemen. Their primary targets consisted of Kyrgyz, Tajik, and Uzbek migrants originating from Uzbekistan's other regions, such as Bukhara, Kashkadarya, Khorezm, Samarkand, and Surkhandarya. In Nodir's view pure ethnic Uzbeks primarily lived in the Fergana Valley, and people living in other regions of Uzbekistan were not pure Uzbeks; that is, they were either mixed with Tajiks or Turkmens. Referring to this "ethnic impurity," Nodir and his team members did not feel guilty extorting money from their countrymen.

In December of 2013, however, Nodir and his team were forced to stop their racketeering activity. Typically, when Nodir extorted money from migrants, the police officers closed their eyes. This gave Nodir and his team absolute immunity. But an incident connected with a Kyrgyz migrant eventually put an end to their business. As usual, Nodir and his team used violence and forcibly took money and a mobile phone from a Kyrgyz migrant. In turn, the Kyrgyz migrant visited the police unit of the station, seeking redress for his grievance. Normally, the police officers did not react to such reports because Nodir paid them regularly. But this time the police officers had to react to this report since they were in the midst of an inspection from their superiors and several high-level police officials were present. The police officers quickly reacted and arrested Nodir and his team members on racketeering and extortion charges. Initially, they denied the charges. But CCTV cameras installed in the station clearly showed that they had indeed committed 
the crimes. It thus became apparent that Nodir and his team's case would be transferred to the prosecutor for further investigation, which would undoubtedly lead to a prison sentence. But, again, Nodir used his bribery skills and quickly offered 100,000 rubles ( $\sim$ US $\$ 3,000$ ) to the head of the police, who was an ethnic Tatar. Since it was a large sum for a bribe, the Tatar police officer happily accepted the offer but on the condition that Nodir and his team would never show up at the railway station again. Otherwise, he would not forgive them if they were caught again. Nodir and his team accepted this condition and immediately ceased their racketeering activity at Kazansky vokzal.

This event significantly changed Nodir's behavior. In the past he would drink vodka and often had sex at different brothels, behavior considered haram (sinful) in Islam. As a result of this incident Nodir became religious and began praying five times a day, a practice followed by devout Muslims. He also returned to the construction sector in January of 2014, where he had begun his "migrant career" in 2010. Because Nodir did not have any immigration documents, it was easy for him to find a job in the construction sector, where employment relationships were conducted on an informal basis. In addition to construction work, Nodir also worked part-time as an "industrial alpinist" (promyshlenniy alpinist), a job that involves climbing trees and trimming weak or dried branches and limbs that pose a risk to pedestrians. Since this job was risky and life-threatening, Nodir received 2,000 to 3,000 rubles ( US\$60-\$100) for each tree he trimmed. Thus, he quickly transitioned from racketeering to daily manual labor in the construction and "alpinist" sectors, which afforded him a positive reputation among his covillagers in Moscow.

Given his street smartness and past racketeering experiences, Nodir was unafraid of facing the police and invented various tactics to avoid paying bribes. When the police stopped and asked him to show his documents, he openly told them that he had no documents and that they can do whatever they want with him. He knew that Russian police officers are only interested in money and would not keep him more than a few hours if he had no money. Since Nodir never carried his passport with him, when asked to provide his passport details, he often provided the passport details of his covillagers who had already left Russia. Thanks to his good memory, Nodir knew the serial number and expiration date of his covillager's passport. When the police checked the passport details he provided, his covillager indeed existed in the database, leading the police officers to believe that he was indeed the same person. Anecdotally, Nodir stated that he had already called his covillager and advised him not to come to Russia in the next five years since Russian police officers had fined him many times, likely resulting in an entry ban.

As an industrial alpinist, Nodir trimmed shrubs in different parts of Moscow and interacted with people from various backgrounds and social classes. In March of 2016, he met Sergey Nikolaev, a high-level official from the Russian Federal Security Service (FSB), when he was trimming shrubs in the apartment building 
where he lived. Because Nodir looked industrious, physically fit, and could communicate in Russian, Sergey Nikolaev offered him a job with a salary of 35,000 rubles ( US\$60o based on 2016 exchange rates) per month. Sergey Nikolaev owned a dacha (summer cottage) in Rublevka, which he rented to tourists and guests all year round. Thus, he needed someone who could work both as a guard and a caretaker to serve the guests. Nodir happily accepted this job offer since he could receive a good salary and work and stay in an elite residential area where only wealthy people live. Because his boss, Sergey Nikolaev, was a high-level FSB official, Nodir did not need any immigration documents and enjoyed free mobility since many local police officers in the Rublevka area knew that he was under the protection of Sergey Nikolaev.

But Nodir was safe only in the Rublevka area. In September of 2016 he went to Moscow city to meet and socialize with his friends at an Uzbek café situated near the Babushkinskaya metro station. This happened to coincide with immigration service raids in the area near the metro and sweeps to catch undocumented migrants for possible deportation. Nodir was caught during this raid and was taken to the police department before court proceedings. The trial took place immediately on the next day, and Nodir received an administrative expulsion and deportation order, meaning he would be transferred to a temporary detention center, where migrants were detained until deportation. Nodir somehow managed to find a phone and quickly called his boss, explaining that he was caught during a raid and that the court had ordered his deportation. Sergey Nikolaev immediately came to the police station where Nodir was detained and had a discussion with the police and immigration officials behind closed doors. Following this, and rather surprisingly, they returned Nodir's passport to him and told him to leave Russia on his own within a 10-day period. Sergey Nikolaev blinked subtly at Nodir and told him to go to the dacha. Thanks to his boss's interference, Nodir was able to avoid the administrative expulsion, while all of the other migrants who were caught were sent to a temporary detention center for deportation. When Nodir reached the dacha, Sergey Nikolaev instructed him to hide his passport somewhere inside the dacha. Instead, he provided Nodir with a letter (spravka) from the police, stating that his passport and immigration documents were lost. With the assistance of his boss, Nodir regularly updated this letter since it provided him with valid justification for not having his documents with him. When stopped by the police or immigration officials on the street, Nodir usually claimed that he had lost his passport and immigration documents and that he would replace them as soon as possible.

I met Nodir for the last time in August of 2018 when completing my last fieldwork trip for this project. He was still working at the dacha under the protection of Sergey Nikolaev. But, since he was already 30 years old, he was considering returning to his home village sometime next year (in 2019) and marrying a girl his parents had found for him. When I asked him whether he was going to remain in 
the village, he said that he would return to Moscow with his wife shortly after the wedding, and they would both work at the dacha. He was confident that Sergey Nikolaev would find ways to remove his entry ban in the GUVM database and ensure his return to Russia. Recalling his racketeering work at Kazansky vokzal and how he changed after that experience, Nodir often compared his migrant life and adventures in Moscow to completing military service, whereby one gradually becomes more disciplined, mature, and street-smart as a result of exposure to hardships, strict rules, and hierarchies.

Being undocumented does not necessarily mean that migrants lose their agency and ability to organize their daily lives. Rather, migrants like Nodir have agency and can invent various strategies to maneuver around structural constraints. This situation results from the corrupt and weak rule-of-law environment in Russia empowering the agency of migrants to navigate the system. Nodir's bribery skills, street smartness, and knowledge of informal rules played a key role in negotiating his legal status and relationship with different law-enforcement bodies. Given that the Russian legal system does not function in accordance with rule-of-law principles and that state actors themselves break laws on a daily basis, migrants also respond to these uncertainties by inventing informal norms and practices that provide some kind of palliative mechanism to organize their precarious livelihoods. Based on Nodir's experiences, we can conclude that migrant legal adaptation in contexts characterized by hybrid regimes such as Russia is not primarily contingent on being "legal" and having authentic immigration documents. More importantly, it is about being able to quickly adjust to changing circumstances, the ability to offer bribes when necessary, to act calmly and cunningly when stopped by law-enforcement officials, and to make the right connections and use them to bend the laws. These street skills and artistic traits are as important as possessing authentic immigration documents.

\section{BAHA: LEARNING HOW TO PERFORM "LEGALITY"}

Baha (29, male) is a migrant worker in Moscow. Shortly after finishing technical college in 2009, Baha landed a job as an electricity fee collector at the district electricity department (a state-owned enterprise) in rural Fergana, Uzbekistan. His main task involved visiting households in the district on a daily basis and collecting electricity fee payments. Because of the high unemployment rate and growing poverty in rural Fergana, many households could not pay for electricity. Given these realities, Baha's job was quite challenging and rife with scandals, given that he either had to force low-income households to pay or cut their line from the power network. In addition, the nonpayment of fees was connected to frequent interruptions in electricity provision, which left people unsatisfied with the work of the district electricity department. Frustrated with the problems with electricity, many people in rural Fergana simply refused to pay. Despite these 
daily challenges in his work, Baha received a very low salary, which was insufficient to secure even his own basic needs. As a result, Baha invented various strategies to supplement his low salary. He helped some households with which he had a good relationship and deleted electricity usage records from their electricity meter. In return, heads of households expressed their gratitude to Baha by giving him 25 percent of the deleted electricity fees. But despite these informal income-earning opportunities, Baha decided to quit his job in June of 2013 and move to Russia as a migrant worker. This decision was driven by Baha's desire to diversify his life and seek new adventures in a new country.

Baha arrived in Moscow on June 12, 2013. Since his father was already working in Moscow, he smoothly entered the labor market. Unlike many Uzbek migrants, who failed to obtain a work permit, Baha quickly applied for and obtained a work permit for a one-year period, allowing him to secure formal employment in the Russian construction company that employed his father. This was possible given that Baha sent a copy of his passport to his father two months before his arrival, giving him sufficient time for the company to facilitate his work permit application. Thus, Baha's migrant life in Moscow began smoothly, and he started working at the construction company three days after his arrival.

Baha's primary task was to wash the tires of vehicles that serviced the construction site. Since the construction site was located in Moscow city, the company had to ensure that no dirt or wet clay was taken out of the construction site into the city, a requirement that generated a job for migrants like Baha. Baha's command of the Russian language was almost nonexistent, but he managed to learn the language quickly thanks to his talkativeness, social skills, and eagerness to communicate with Russian girls. Baha's monthly salary was 22,00o rubles ( US\$70o based on 2013 exchange rates). But, his employment contract listed his official salary as 10,000 rubles ( $\sim$ US $\$ 300$ ), and he received the remaining 12,00o rubles ( $\sim$ US $\$ 400$ ) in a separate envelope, a typical tax evasion practice widespread in many postSoviet countries. Each time he received his salary, Baha had to sign two different vedomost (payment register books): a white vedomost that was a public register and a black vedomost that was kept secretly. Since Baha was formally employed, he worked five days a week and stayed in the free accommodation (a hostel) provided by the company.

Baha's stable life came to an end in May of 2014, when his father returned to Uzbekistan. Another contributing factor to this instability revolved around tensions associated with ethnic differences. While many migrants at the construction site were from the Fergana Valley, many of them were ethnic Tajiks and did not share a common ethnic identity with Baha. This ethnic difference led to serious tensions between Uzbek migrants like Baha and ethnic Tajik migrants, who constituted the majority of workers at the construction site. Given these tensions and some brawls, Baha and several other migrants were compelled to quit their job, an event that completely changed Baha's migrant life in Moscow. 
This period was the first time Baha was on his own in a foreign country. But he had extensive village networks in Moscow that he could rely on when necessary. Before contacting his covillagers, Baha visited two construction companies but was refused a job since his work permit was about to expire within a month. This meant Baha had to obtain a new work permit to continue working legally in the construction company. But, in order to prolong their working period in Russia, migrants are required to leave and reenter the territory of Russia once each year. The Russian authorities keep immigration flows under control by legally requiring migrants to renew their migration card and exit-entry stamp. Because Baha worked in Moscow, the closest border was the Pogar border checkpoint in the Bryansk province along the Russian-Ukrainian border. Thus, Baha also decided to travel to Pogar to renew his migration card and the exit-entry stamp in his passport.

Thousands of migrant workers travel to the Pogar border checkpoint by shared taxi once a year to get a new exit-entry stamp in their passport. Pogar is a small town situated on the Russian-Ukrainian border. The distance from Moscow to Pogar is about 505 kilometers, or at least an eight-hour drive. In Russia, Federal Security Service (FSB) troops are responsible for protecting the national border. FSB troops (a) administer and oversee all border control checkpoints, procedures, and infrastructures; (b) review the documents of individuals, goods, and transport vehicles crossing the Russian border; and (c) perform law-enforcement functions in the borderland.

When migrants arrive at the Pogar border crossing, they have two options. The first option is that the migrant waits in the queue at least eight hours to reach passport control in order to obtain an exit stamp and leave the Russian territory. After exiting Russia, the migrant walks toward the neutral zone between Russia and Ukraine and then walks back to the Russian passport control section in order to reenter Russia and obtain a new entry stamp in her/his passport. When reentering Russia, each migrant is required to pay a 500-ruble ( US $\$ 8$ ) bribe to the border control official who puts an entry stamp in the passport. This is a well-established norm, whereby all migrants know about this and insert 500 rubles into their passport when handing it over to the border official.

The second option is to cross the border via a special bus, located at a nearby gas station. The fee for the bus service is 1,500 rubles ( US\$25). The advantage of using the bus service is that migrants do not have to wait in the queue; thus, they obtain their exit-entry stamp within two to three hours, without even getting off the bus. The bus driver collects all of the passports and gets the stamps for everyone on the bus. On average, for each border crossing trip, this bus takes 40 passengers, and approximately 15 to 20 buses serve the border trips. Each day, at least 50 bus trips are organized, meaning at least 2,00o migrants use this bus service. This bus business generates approximately 3 million rubles ( US\$47,00o) per day. The profit from this service is shared between the border control officials (FSB 
troops) and the individuals who organize the bus service. Since this bus service is informally organized, all of the transactions described above are illegal and serve as a source of kormushka (a feeding trough) for border officials.

In late May of 2014, Baha, together with three migrants, traveled to Pogar via shared taxi. Each migrant-passenger paid 4,500 rubles ( US\$70) for the return trip. The trip to the border took about 10 hours since the car was frequently stopped by traffic police officers who checked the driver's and the migrants' identity documents. Since one of the migrants did not have a residence registration, he had to pay a bribe to several police officers along the route.

They arrived at the border at about 8 a.m. Following the advice of their taxi driver, Baha and the other three migrants used the bus service and quickly exited the territory of Russia. But, when returning to Russia, Baha was asked to get off the bus and talk to a passport control official. After a quick conversation with the border control official, it became clear that Baha had an entry ban, meaning he was not allowed to return to Russia. It was a catch-22 situation since Baha was neither allowed to enter Russia because of the entry ban nor enter Ukraine given the tensions between Russia and Ukraine over Crimea. Baha had no option but to enter Russia, even if it was a criminal act. Not wanting to get stuck in the neutral zone, Baha approached the Ukrainian border official and asked him whether he could help him enter Russia. The Ukrainian border official answered that he could help Baha if he gave him 10,000 rubles ( US\$160). The Ukrainian official said that he could provide a document that states that Baha was not allowed to enter Ukraine, thereby forcing the Russian border officials to accept him since he came to the Ukrainian border through the Russian territory.

But Baha did not have 10,000 rubles with him. Baha contacted his covillager Misha in Moscow, asking him to come to Pogar and lend him money so that he could return to Russia. Eight hours later, his friend Misha arrived at the border checkpoint with the money and contacted the Russian border guards to pass the money to Baha, who waited on the other side of the border. In response the border officials offered two options: (a) Misha himself could cross the border officially or (b) he would give the money to taxi drivers (there were taxi drivers nearby who worked for the Russian border officials), and those drivers would give the money to Baha. Since Misha also had an entry ban, he could not consider the first option. This represented a very interesting situation because the Russian border officials themselves offered the solution to the problem. Simultaneously, they made sure that they would make some money through the taxi drivers. Misha quickly made a deal with a taxi driver for 5 , 000 rubles ( $\sim$ US $\$ 80$ ) as payment for their services and gave them 10,000 rubles to deliver to Baha. Misha knew that Baha might need more money, so he hid another 10,000 rubles inside the bread that the driver was also delivering to Baha. He did so because the taxi driver could have raised the fee if he knew that he was carrying that much money. This strategy worked well; Baha received 20,000 rubles ( $\sim$ US $\$ 325$ ) and bread to sustain him. 
After receiving the money, Baha passed 10,000 rubles to the Ukrainian border official, who in turn promised to get the document ready in one hour. Baha waited for more than two hours, but the official did not show up. Exhausted, given his long wait, Baha approached other Ukrainian border guards and asked them for the agreed-on certificate. The border guards told him that the official who took the money had already left for the day and would not return until two days later. Baha became angry and shouted at them, but the border guards threatened that they would shoot Baha if he did not stop immediately. Frightened, Baha returned to the neutral zone.

Baha again started looking for different ways to solve his problem. This time, he tried to negotiate with Ukrainian border guards in other ways. The guards told Baha that they could help him enter Russia through alternative roundabout ways for 7,00o rubles ( US\$110). Luckily, the Ukrainian border guards kept their word and guided him to where he could enter Russia illegally. This strategy was quite risky: if the Russian border guards caught him, he could have been either shot or faced a prison sentence. Baha was lucky; he crossed the border safely and immediately returned to Moscow with Misha.

This incident designated Baha as totally "illegal" in Russia. But with Misha's assistance, Baha again became "legal" and got a fake entry stamp in his passport from Kazansky vokzal confirming his "official" entry to Russia. Baha also obtained a fake residence registration and work permit from Kazanskiy vokzal, allowing Baha to navigate situations when stopped by police officers. It was not difficult to find accommodation. Baha stayed in a shared apartment with 14 other tenants, three of whom were his covillagers. Because Baha lacked a work permit, he worked for different middlemen in the construction sector from May of 2014 through November of 2015. But he often had problems with delays or nonpayment of his salary given the handshake (informal) nature of his employment. All of the middlemen who did not pay Baha's salary typically blamed the Russian construction company or the Russian middlemen for payment problems, a justification commonly used by various middlemen. As a result, Baha could not send money home and used his meager income to cover his living expenses in Moscow, which included costs such as accommodation, food, clothes, transport, fake documents, and bribes to police officers.

In December of 2015, with the assistance of his covillagers, Baha got another job at a construction site in Balashikha, a small town in Moscow province. He joined one of the construction teams primarily consisting of his covillagers who did finishing and design work (e.g., painting, flooring, and window installation) in nearly completed residential buildings. This construction site served both as a workplace and accommodation for the migrants working there. Their boss was an Uzbek middleman, who in turn was accountable to a Russian middleman and the construction company. Although there were monthly delays, Baha and his covillagers were paid for their work. But despite this, Baha did not like working 
in Balashikha. This was due to the fact that Balashikha used to be a forbidden, military town during Soviet times and at that time foreigners were not allowed to work there. But this historical fact was misused by Russian police officers, who claimed that Balashikha still preserved its forbidden zone status in the post-Soviet period. Using this argument, police officers extorted bribes from the migrant workers. Therefore, many migrants did not leave the construction building and spent most of their time inside. Because Baha was an outgoing and sociable person, he liked walking outside and was often caught by a hungry police officer constantly looking for migrants to extort. Given the daily police corruption, Baha decided to quit this job in September of 2016.

Baha was the eldest son in his family, so his parents had high expectations of him. Baha knew that jumping from one job to another would not lead to success. Thus, he started exploring different possibilities to find a stable, well-paying job. Fed up with con-artist migrant middlemen, Baha tried to avoid them and work directly under Russian people who, in Baha's view, were honest and never cheated migrants (o'ris aldamaydi). But to find such work, he needed to have a Russian passport or at least a Kyrgyz passport that would allow him to work without a work permit given the inclusion of Kyrgyzstan in the Eurasian Economic Union. Kyrgyz migrants were, thus, in greater demand on the labor market since they could work in Russia without a work permit, a factor making them more easily employable than Tajik and Uzbek migrants.

In October of 2016 Baha bought a fake Kyrgyz passport from an underground printing house at Kazansky vokzal. One of his friends, a migrant from Uzbekistan's Navoiy region, also had a Kyrgyz passport, which he used to get a job as a loader at a warehouse in Moscow that supplied different wine and liquor products (both Russian and European) to many stores in Moscow. Based on his friend's recommendation, Baha also got a job as a loader at the warehouse in November of 2016. Since Kyrgyz citizens are not required to have a work permit, the manager of the warehouse did not notice that Baha and his friend had fake passports. Using his fake Kyrgyz passport, the warehouse manager quickly employed Baha with a salary of 35,000 rubles ( $\sim$ US\$55) per month, allowing him to send money home, as well as have some money for daily expenses in Moscow. The manager also allowed Baha to use one of the empty rooms in the warehouse as accommodation.

Given these privileges, Baha's life changed considerably. He also quickly learned how to avoid paying bribes to police officers. When walking on the street and in public places, Baha usually did not carry any identity documents with him. Baha admired Chechens for their ability to "rule the street" and had several Chechen friends from Grozny, the capital of Chechnya. Like Chechens, Baha wore sport clothes and grew a long beard. When stopped by the police, Baha often introduced himself as a Chechen to the police officers. Naturally, the police officers did not initially believe him because of the absence of his identity document. But after Baha provided the passport details of his Chechen friend who resembled him 
and even recalled the name of the street and house in Grozny where his friend was registered, the police officers let him go. In some cases Baha presented himself as a victim of human trafficking, telling the police that he lost his passport and was exploited by Armenians who locked him in a small factory for five years. He told the police that he was waiting for a temporary identity document issued by the Uzbek embassy and would return to Uzbekistan as soon as he received it from the embassy. Baha also knew that the police officers were good psychologists and usually stopped those migrants who were not well-dressed. Therefore, Baha usually invested in decent clothes with his salary so that he would differ from those migrants who did "black work" (qora ish). He often stated that it was better to invest in one's clothes and appearance than paying a bribe to police officers. In short, Baha invented various strategies and stories to avoid paying a bribe to the police.

I visited Moscow for the last time in August of 2018 and found that Baha was still working at the same warehouse. But to my surprise Baha was considering marrying a Russian girl in Moscow who was originally from Orenburg, a city in southwest Russia. Already engaged then, their wedding took place in Moscow in March of 2019. Currently, Baha is trying to legalize his status in Russia using his wife's Russian citizenship. It is unclear whether he will accomplish this objective.

As Baha's brief life history shows, it is quite difficult for migrants to remain "legal" in Russia given the punitive legal environment. Instead, it is easier to adapt to the legal environment by inventing various informal and illegal strategies and tactics. Despite Baha's attempts to remain "legal" by extending his work permit, the entry ban he received for minor administrative offenses and his subsequent border adventures made it impossible for him to pursue formal paths to legal adaptation. As a result, Baha resorted to informal, street-based mechanisms of legal adaptation that provided him with more economic security and a better job even though this path carries significant risks. But given the fact that "becoming legal through illegal practices" is common in migrant Moscow, Baha's strategy represents a widespread means of legal adaptation in the Russian context. This practice is not an exception, but rather a way of life for many migrants in contemporary Russia.

Drawing from three Uzbek migrants' life histories, this chapter has demonstrated how being undocumented does not automatically deprive migrants of their agency. Instead, it encourages them to invent various informal tactics, strategies, and practices to navigate through the restrictive legal environment. These life histories illustrate how migrant workers, despite their "illegal" status, remain resilient and resourceful, displaying a significant capacity to maneuver around the structural constraints. These constraints include complicated residence registration and work permit rules, punitive laws, social exclusion, racism, and the lack of a social safety net. We have seen that migrants are not just passive, agencyless subjects constrained by a restrictive legal environment but are capable of shaping 
and adapting their daily routines, mundane social interactions, and "legalization" strategies to the conditions of a shadow economy, a corrupt law-enforcement system, and the lack of any rule-of-law context.

Thus, in line with Garcés-Mascareñas (2010) and Sigona (2012), I contend that researchers must recontextualize the experience of being undocumented and examine it not as an essentialized, generic, and uniform condition. Instead, we should examine this experience as a phenomenon contingent on geographical, political, and historical factors, on the one hand, and migrants' agency and experiences, on the other. Hence, we need a more context-sensitive understanding of "migrant undocumentedness" that takes into account how lacking a legal status intersects with the sociolegal environment and the broader sociopolitical context and, simultaneously, migrants' agency, experiences, and histories. In this regard "illegality" in some migration contexts may actually enable migrants to navigate around the constraints imposed by the state-regulated migrant labor system. 